\title{
Production and quality of okra produced with mineral and organic fertilization
}

\author{
Hemmannuella C. Santos ${ }^{1}$, Emmanuel M. Pereira ${ }^{2}$, Rafael L. S. de Medeiros ${ }^{3}$, \\ Paulo M. de A. Costa ${ }^{4}$ \& Walter E. Pereira ${ }^{5}$
}

${ }^{1}$ Instituto Federal de Educação, Ciência e Tecnologia de Pernambuco/Departamento de Desenvolvimento Educacional. Vitória de Santo Antão, PE. E-mail: hecosantos@vitoria.ifpe.edu.br (Corresponding author) - ORCID: 0000-0003-4871-1875

${ }^{2}$ Universidade Estadual Paulista/Faculdade de Ciências Agrárias e Veterinárias. Jaboticabal, SP. E-mail: emmanuel16mop@hotmail.com - ORCID: 00000003-4097-5796

${ }^{3}$ Universidade Federal da Paraíba/Centro de Ciências Agrárias/Unidade Acadêmica de Bacharelado em Agronomia. Areia, PB. E-mail: rafaelluisufpb@yahoo.com.br ORCID: 0000-0002-1597-2772

${ }^{4}$ Universidade Federal da Paraíba/Centro de Ciências Humanas, Sociais e Agrárias/Curso de Bacharelado em Agroecologia. Bananeiras, PB. E-mail: paulomarks90@hotmail.com - 0000-0001-6411-745X

${ }^{5}$ Universidade Federal da Paraíba/Centro de Ciências Agrárias/Departamento de Ciências Fundamentais e Sociais. Areia, PB. E-mail: wep@cca.ufpb.br ORCID: 0000-0003-1085-0191

\begin{abstract}
Okra, Abelmoschus esculentus (L.) Moench, is a vegetable with annual fruit native to hot regions of Africa, well adapted to the conditions of the Northeast and Southeast regions of Brazil, where it is widely used by small farmers. This study aimed to evaluate the effect of mineral and organic fertilization on the production and quality of okra fruits. The experiment was conducted in randomized block design, with three replicates and eleven treatments defined according to a Baconian matrix. Treatments consisted of doses of $\mathrm{N}\left(0,100,200\right.$ and $\left.300 \mathrm{~kg} \mathrm{ha}^{-1}\right), \mathrm{P}\left(0,100,200\right.$ and $\left.300 \mathrm{~kg} \mathrm{ha}^{-1}\right)$ and $\mathrm{K}\left(0,80,160\right.$ and $\left.240 \mathrm{~kg} \mathrm{ha}^{-1}\right)$, as well as absence and presence of organic compost $\left(30 \mathrm{tha}^{-1}\right)$. The following parameters were evaluated: plant height, stem diameter, number of leaves, production of fruits plant ${ }^{-1}$, number of fruits plant ${ }^{-1}$, fruit length and diameter and fruit quality ( $\mathrm{pH}$, soluble solids, titratable acidity, vitamin $\mathrm{C}$ and electrical conductivity). The crop is demanding in terms of $\mathrm{K}$ and $\mathrm{N}$ fertilizations, with increments of 15.8 and $36 \%$ in the mean number and diameter of fruits, respectively. Organic fertilization did not influence the vegetative growth of okra, but was beneficial to the production of fruits with higher vitamin C content, $52 \%$ higher than the contents found in fruits produced without such input.
\end{abstract}

Key words: Abelmoschus esculentus (L.) Moench, Baconian matrix, vegetable, postharvest

\section{Produção e qualidade de quiabo produzido com adubação mineral e orgânica}

RESUMO: A cultura do quiabeiro Abelmoschus esculentus (L.) Moench é uma hortaliça de fruto anual originária de regiões quentes da África tendo se adaptado bem às condições das regiões Nordeste e Sudeste do Brasil, onde é uma cultura muito utilizada por pequenos agricultores. Objetivou-se avaliar o efeito da adubação mineral e orgânica na produção e qualidade de frutos de quiabeiro. O delineamento experimental foi em blocos casualizados, com três repetições e onze tratamentos definidos segundo uma matriz baconiana. Os tratamentos consistiram de doses de $N^{\prime}\left(0,100,200\right.$ e $\left.300 \mathrm{~kg} \mathrm{ha}^{-1}\right), \mathrm{P}\left(0,100,200\right.$ e $\left.300 \mathrm{~kg} \mathrm{ha}^{-1}\right)$ e K $(0,80$, 160 e $\left.240 \mathrm{~kg} \mathrm{ha}^{-1}\right)$ e ausência e presença de composto orgânico $\left(30 \mathrm{t} \mathrm{ha}^{-1}\right)$. Foram avaliados a altura de plantas, diâmetro do caule, número de folhas, produção de frutos planta ${ }^{-1}$, número de frutos planta ${ }^{-1}$, comprimento $\mathrm{e}$ diâmetro dos frutos, e a qualidade dos frutos $(\mathrm{pH}$, sólidos solúveis, acidez titulável, vitamina C e condutividade elétrica). A cultura é exigente quanto à adubação potássica e nitrogenada, com aumentos no número médio e diâmetro de frutos, 15,8 e 36\%, respectivamente. A adubação orgânica não influenciou o crescimento vegetativo do quiabeiro, no entanto, foi benéfica à produção de frutos com maior teor de vitamina $\mathrm{C}, 52 \%$ maior que os frutos produzidos sem esse insumo.

Palavras-chave: Abelmoschus esculentus (L.) Moench, matriz baconiana, olerícola, pós-colheita 


\section{INTRODUCTION}

Okra is a vegetable originated from Africa, cultivated under rainfed or irrigated conditions in a wide variety of soils, and is one of the most important vegetables in the world, especially in tropical and subtropical climates (Marin et al., 2017), due to its rusticity and tolerance to heat, not requiring high levels of technology for its cultivation (Oliveira et al., 2003). However, it is sensitive to salinity, with a reduction of up to $70 \%$ in the production of fresh fruits in comparison to plants cultivated in non-saline soils (Kamaluldeen et al., 2014), and to the attack of Coleoptera insects (Pitan \& Ekoja, 2011).

This crop plays an important role in human diet due to the supply of carbohydrates, proteins, fats, minerals and vitamins (Abd El-Kader et al., 2010). It has vitamins A and C, being a source of calcium, iron, niacin, in addition to having medicinal qualities (Oliveira et al., 2014), and it has also attracted recent interest as an industrial source of fiber. Additionally, its seeds provide high-quality oil and the mucilage from its fruit can be used as a thickener in food industry (Alegbejo et al., 2008).

Okra responses to mineral and organic fertilization have been observed by several researchers (Oliveira et al., 2007; Omatoso \& Shittu, 2007; Abd El-Kader et al., 2010; Cardoso $\&$ Berni, 2012). Mineral nutrition of vegetables can influence their development with subsequent effects on quality. The Soil Fertility Commission of Minas Gerais (CFSMG, 1999) and the Agronomic Institute of Campinas (Raij et al., 1996) indicate doses from 20 to $120 \mathrm{~kg} \mathrm{ha}^{-1}$ of $\mathrm{N}$, from 40 to $300 \mathrm{~kg} \mathrm{ha}^{-1}$ of $\mathrm{P}_{2} \mathrm{O}_{5}$ and from 20 to $240 \mathrm{~kg} \mathrm{ha}^{-1}$ of $\mathrm{K}_{2} \mathrm{O}$, and from 10 to $50 \mathrm{t} \mathrm{ha}^{-1}$ of manure. However, these recommendations may be outdated with the development of cultivars that are more productive and consequently more demanding in terms of nutrients. Therefore, more specific studies are needed to provide recommendations of fertilizers for each region.

Besides mineral fertilization, the application of organic fertilizers has been considered as important for vegetable production. The strategy is to use this input at doses that maximize yield, adding mineral fertilizers in complementary quantities, which would reduce production costs (Oliveira et al., 2014). Given the above, this experiment aimed to evaluate the production and quality of okra fruits produced with mineral and organic fertilization.

\section{Material ANd Methods}

The experiment was conducted in the Agriculture Sector of the Center of Human, Social and Agrarian Sciences of the Federal University of Paraíba (CCHSA/UFPB), Campus III, Bananeiras, PB, from September 2014 to February 2015, encompassing the period from planting to harvest.

The climate in the municipality of Bananeiras was classified, according to Thornthwaite (1948), as C1dB'4a', dry sub-humid, without or with slight water surplus, mesothermal and with annual rainfall of $1174.7 \mathrm{~mm}$ and mean temperature of $22.4^{\circ} \mathrm{C}$. The soil in which the experiment was conducted was classified by Brasil (1972) and reclassified as typic dystrophic Yellow Latosol, according to EMBRAPA (2013). It has the following chemical characteristics, determined according to the methodology described in EMBRAPA (2017) (Table 1).

Treatments were defined according to a Baconian matrix (Turrent, 1979), testing eleven treatments (Table 2) arranged in randomized blocks, with three replicates. Doses of $\mathrm{N}(0$, 100,200 and $\left.300 \mathrm{~kg} \mathrm{ha}^{-1}\right), \mathrm{P}\left(0,100,200\right.$ and $\left.300 \mathrm{~kg} \mathrm{ha}^{-1}\right)$ and $\mathrm{K}\left(0,80,160\right.$ and $\left.240 \mathrm{~kg} \mathrm{ha}^{-1}\right)$, as well as presence and absence of organic compost $\left(30 \mathrm{t} \mathrm{ha}^{-1}\right)$ were evaluated.

The organic compost was previously prepared in the area, with bovine manure and plant residues, and was applied in the quantity of $30 \mathrm{t} \mathrm{ha}^{-1}$, being subsequently incorporated to the soil in the plot relative to this treatment. The chemical characteristics of the compost were determined according to the methodology described in EMBRAPA (2013) and are presented in Table 3.

The experiment began by directly sowing the okra cultivar 'Santa Cruz' at spacing of $0.6 \times 0.5 \mathrm{~m}$, placing three seeds per pit at depth of approximately $3 \mathrm{~cm}$. Prior to sowing, seed dormancy was broken by the method of immersion in cold water for $24 \mathrm{~h}$, with subsequent drying in the shade (Filgueira, 2008). Thinning was performed when plants were 15 to $20 \mathrm{~cm}$ tall, leaving one plant per hole.

Soil tillage consisted of plowing and harrowing, with subsequent cleaning of the area and application of treatments. Urea, single superphosphate and potassium chloride were used as sources of $\mathrm{N}, \mathrm{P}$ and $\mathrm{K}$, applied at the bottom of the hole, in plots that received mineral fertilization.

Phytosanitary control was performed with the spiromesifen Oberon to control aphids (Aphis spp.) as recommended by the manufacturer. The area was weeded three times along the crop cycle to avoid competition for water and nutrients. The crop was grown until harvest, which began 73 days after planting. The period from flowering to harvest is approximately 4 days (Silva et al., 2007).

Table 2. Doses of $\mathrm{N}, \mathrm{P}_{2} \mathrm{O}_{5}, \mathrm{~K}_{2} \mathrm{O}$ and organic fertilization per treatment

\begin{tabular}{|c|c|c|c|c|}
\hline Treatments & $\mathbf{N}$ & $\frac{\mathrm{P}_{2} \mathrm{O}_{5}}{\mathrm{~kg} \mathrm{ha}}$ & $\mathrm{K}_{2} \mathrm{O}$ & $\begin{array}{l}\text { Organic fertilization } \\
\text { (t ha } \mathrm{h}^{-1} \text { ) }\end{array}$ \\
\hline $1^{1}$ & 200 & 200 & 160 & 0 \\
\hline 2 & 0 & 200 & 160 & 0 \\
\hline 3 & 100 & 200 & 160 & 0 \\
\hline 4 & 300 & 200 & 160 & 0 \\
\hline 5 & 200 & 0 & 160 & 0 \\
\hline 6 & 200 & 100 & 160 & 0 \\
\hline 7 & 200 & 300 & 160 & 0 \\
\hline 8 & 200 & 200 & 0 & 0 \\
\hline 9 & 200 & 200 & 80 & 0 \\
\hline 10 & 200 & 200 & 240 & 0 \\
\hline 11 & 200 & 200 & 160 & 30 \\
\hline
\end{tabular}

${ }^{1}$ Reference treatment

Table 1. Chemical analysis of the soil where the experiment was conducted

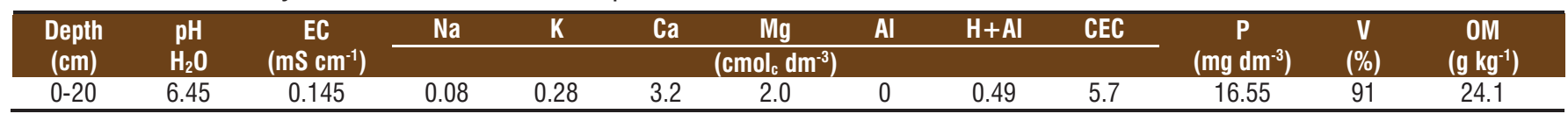


Table 3. Chemical analysis of the organic compost used

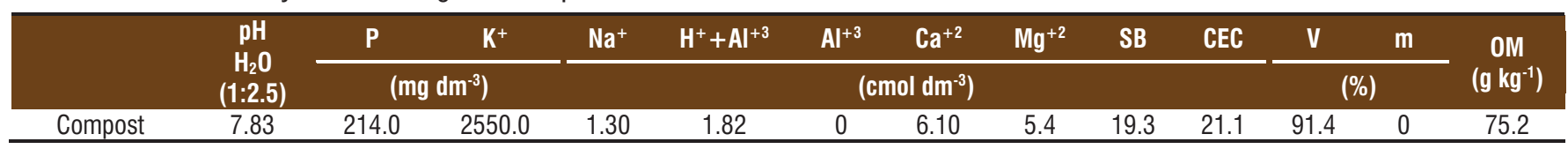

The following parameters were evaluated: stem diameter $(\mathrm{cm})$ and number of leaves; production per plant $\left(\mathrm{g} \mathrm{plant}^{-1}\right)$; number of fruits per plant; fruit length $(\mathrm{cm})$ and diameter $(\mathrm{cm})$ and plant height $(\mathrm{cm})$.

The postharvest attributes evaluated were:

- Contents of soluble solids (SS): read in digital refractometer with automatic compensation of temperature;

- Titratable acidity (TA): acidity was measured in $5 \mathrm{~g}$ of pulp, homogenized in $45 \mathrm{~mL}$ of distilled water and the solution containing the sample was titrated with $0.1 \mathrm{~N} \mathrm{NaOH}$ until reaching the turning point of the phenolphthalein indicator (Ryan \& Dupont, 1973);

- $\mathrm{pH}$ : obtained by the potentiometric method, calibrating the $\mathrm{pH}$ meter with buffer solutions ( $\mathrm{pH} 4.0$ and 7.0 ) at $20^{\circ} \mathrm{C}$;

- Ascorbic acid (AA): estimated by titration, using $5 \mathrm{~g}$ of pulp mixed with $45 \mathrm{~mL}$ of $0.5 \%$ oxalic acid and titrated with Tillmans' solution until the color changed to pink, according to the method described by AOAC (2005);

- Electrical conductivity (EC): determined in the juice according to the number of replicates, using a benchtop digital conductivity meter to estimate the content of electrolytes.

The results were subjected to analyses of variance and polynomial regression, testing linear and quadratic models, and selecting the one capable of best expressing each characteristic. Tukey test was applied to compare the means of organic fertilization, using the program Sisvar.

\section{Results AND Discussion}

The doses of $\mathrm{N}_{2} \mathrm{P}_{2} \mathrm{O}_{5}$ and $\mathrm{K}_{2} \mathrm{O}$ or absence and presence of organic fertilization had no significant effect on the variables analyzed, except the mean number and mean diameter of fruits, which responded positively to $\mathrm{K}$ and $\mathrm{N}$ fertilizations, respectively.

The mean values of the agronomic characteristics plant height, number of leaves and stem diameter were $167.73 \mathrm{~cm}$, 56.5 leaves and $28.86 \mathrm{~mm}$, respectively. Possibly, the high contents of nutrients in the soil (Table 1) before treatment application was responsible for the lack of response. In addition, the time of cultivation may have been insufficient for the mineralization of the compost and release of the nutrients. According to Oliveira et al. (2014), the probability of occurrence of okra response to the use of bovine manure with respect to the production of marketable fruits can be minimized when the content of organic matter is high. In the present study, the organic matter content is considered as intermediate, which may have reduced the response to organic fertilization.

These results differ from those found in the literature, which indicate positive effects of mineral and/or organic fertilization on okra. Tivelli et al. (2013) observed mean height of $160.9 \mathrm{~cm}$ in okra plants, when intercropped with small-size leguminous species, a height slightly smaller than that found in the present study. On the other hand, Tiamiyu et al. (2012) found increments of 37.8 and $39.4 \%$ in the number of leaves and plant height, respectively, with the use of poultry manure, but obtained smaller height and number of leaves, 33 to $44 \mathrm{~cm}$ and 20 to 25 leaves, respectively, compared with the values in the present study. The use of poultry manure was also responsible for the increments of $27 \%$ in plant height $(69.6 \mathrm{~cm})$ and $111 \%$ in stem diameter $(4.8 \mathrm{~cm})$, as observed by Abd El-Kader et al. (2010). In general, these studies were conducted in soils with low contents of nutrients, which would be more responsible to fertilization than that of the present study.

Phonglosa et al. (2015) observed that okra yield, absorption of macro- and micronutrients by okra pods and available nutrient status in post-harvest soil increased significantly when mineral fertilization with $\mathrm{N}$ and $\mathrm{P}$ was supplemented with organic fertilizers.

In relation to the fruits, the production per plant, number of fruits, diameter and length were evaluated and their mean values were $72.40 \mathrm{~g} \mathrm{plant}^{-1}, 10.85$ fruits plant $^{-1}, 2.42$ and $10.34 \mathrm{~cm}$, respectively.

Figure $1 \mathrm{~A}$ shows a $36 \%$ increase in the mean number of fruits as $\mathrm{N}$ doses increased. The dose of $300 \mathrm{~kg} \mathrm{ha}^{-1}$ of $\mathrm{N}$ is much higher than the recommended for the crop, according to Filgueira (2008), who indicates $20 \mathrm{~kg} \mathrm{ha}^{-1}$ of $\mathrm{N}$, and the Agronomic Institute of Campinas (Raij et al., 1996), which
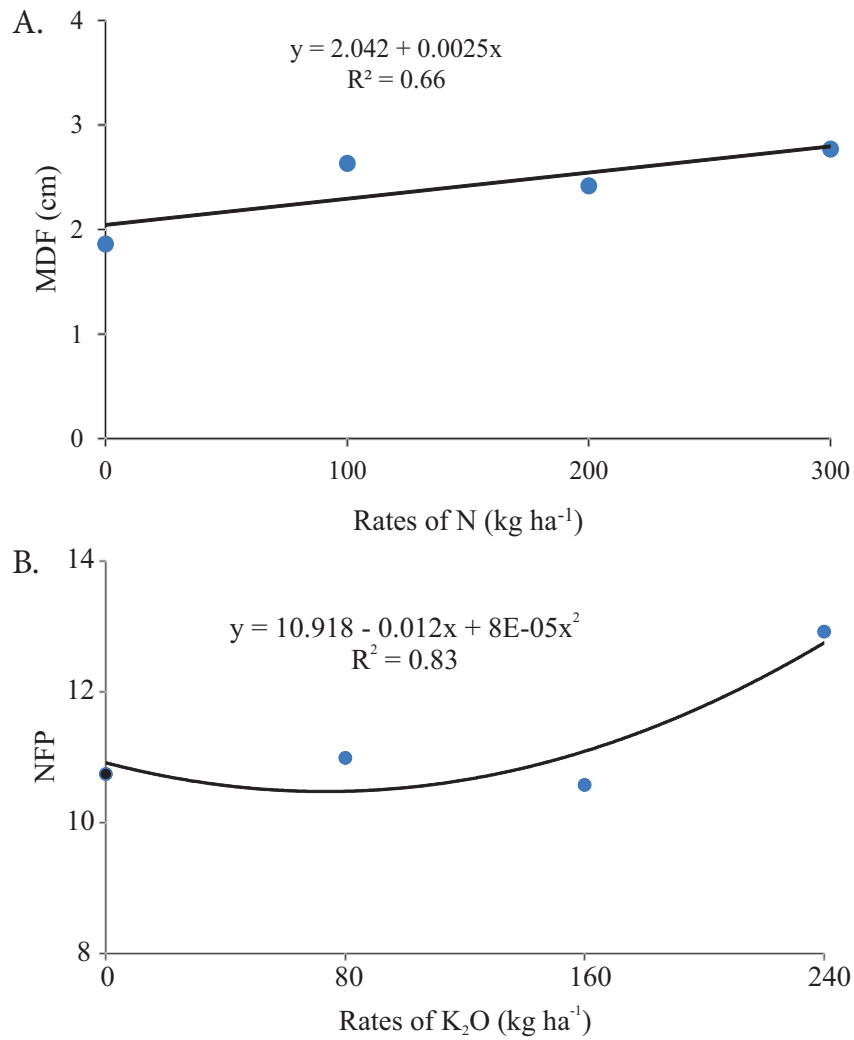

Figure 1. Mean diameter of okra fruits (MDF) as a function of doses of $N(A)$ and number of okra fruits per plant (NFP) as a function of doses of $\mathrm{K}_{2} \mathrm{O}(\mathrm{B})$ 
indicates $40 \mathrm{~kg} \mathrm{ha}^{-1}$ of N. On the other hand, the Soil Fertility Commission of Minas Gerais (CFSMG, 1999) indicates $120 \mathrm{~kg} \mathrm{ha}^{-1}$ of $\mathrm{N}$, and this dose is the closest one to that applied in the present study. Although it is a very high dose, there was response of the crop, but this dose would not be financially feasible for the farmer.

Studies of Adekyia et al. (2018) indicate that urea alone at dose of $60 \mathrm{~kg} \mathrm{ha}^{-1}$ caused optimal yield of okra fruits, whereas fruit growth and mineral composition increased when the dose of $120 \mathrm{~kg} \mathrm{ha}^{-1}$ of urea was applied. In other words, if the goal is only production, lower doses can be applied with good results, but if one intends to produce fruits with higher nutritional quality, higher doses are required by the crop.

The efficiency of $\mathrm{N}$ may be related to the fact that this nutrient is a constituent of proteins, which act in the absorption of nutrients by plants, participates in various biological processes, such as photosynthesis, respiration, synthesis in general, multiplication, cellular differentiation; and increase in the production of vegetative and flower gems (Malavolta, 2002; Filgueira, 2008; Cardoso \& Berni, 2012).

The number of okra fruits increased by $9.10 \%$ with the application of $240 \mathrm{~kg} \mathrm{ha}^{-1}$ of $\mathrm{K}$, compared with the control, which indicates that the crop is very demanding in terms of $\mathrm{K}$ fertilization for fruit production (Figure 1B).

Adequate $\mathrm{K}$ doses in crops favor the formation and translocation of carbohydrates and efficient use of water by the plant, balance the application of $\mathrm{N}$ and improve the quality of the product, regarding aspects such as color, taste and culinary properties, besides adding value in the market (Pinheiro et al., 2011).

Potassium acts as an enzyme activator in mechanisms of synthesis and degradation of organic compounds, participates in the mechanism of stomatal opening and closure, and osmoregulation, among other processes, and improves the quality of the product and its market value (Daliparthy et al., 1994; Filgueira, 2008), thus being the most abundant cation in the plant, affecting the yield and quality of the products harvested. Babatola (2006) claims that $\mathrm{K}$ favors the formation and translocation of carbohydrates and improves the quality of okra fruits.

By comparing the data obtained in the present study with the literature, it is observed that fruit length $(10.34 \mathrm{~cm})$ and production per plant $\left(72.40\right.$ g plant $^{-1} / 10.85$ fruits plant $\left.{ }^{-1}\right)$ were greater than those found by Omatoso \& Shittu (2007), $6.64 \mathrm{~cm}$ and 45.56 g plant $^{-1}$, under mineral fertilization with NPK, and smaller than those found by Tivelli et al. (2013), $16.4 \mathrm{~cm}$ and 10.1 fruits plant ${ }^{-1}$, respectively.

The mean number of fruits was lower than those observed by Oliveira et al. (2007, 2014), 43 and 26 fruits plant $^{-1}$, respectively. These data may result from the cultivar used in the above-mentioned studies, which compensates smaller fruits with higher fruit production.

There were significant effects of $\mathrm{K}$ doses on $\mathrm{pH}$, soluble solids and titratable acidity, and of organic fertilization on vitamin $\mathrm{C}$ and titratable acidity.

As $\mathrm{K}$ doses increased, there were linear reductions in the $\mathrm{pH}$ and titratable acidity (TA) of okra fruits on the order of 3.9 and $35.1 \%$, respectively (Figures $2 \mathrm{~A}$ and B). Potassium acts mainly in the synthesis of some enzymes and as a catalyst for metabolic reactions. This decrease in fruit $\mathrm{pH}$ (Figure $2 \mathrm{~A}$ ) can be attributed to the synthesis of enzymes, which causes the production of acid compounds, such as malic acid. On the other hand, the decline in TA, with the increase in $\mathrm{K}_{2} \mathrm{O}$ doses (Figure 2B), can be attributed to the consumption of organic acids that are dissolved in the cell sap.

Increasing doses of $\mathrm{N}$ resulted in an $11 \%$ increase in the soluble solids (SS) of okra fruits (Figure 2C). N mainly influences the production of biomass and, indirectly, the production of photoassimilates, which in turn are dispersed in the cell sap, many of them present in soluble solids, like some sugars, justifying this increase as function of the increasing doses of $\mathrm{N}$.

Regarding organic fertilization, only ascorbic acid and titratable acidity responded positively to its application (Table 4); vitamin C content increased by $52 \%$ while the titratable acidity increased by $35 \%$ with the application of $30 \mathrm{t} \mathrm{ha}^{-1}$ organic compost. Pradeepkumar et al. (2017) indicate that the effect of organic nutrition was significant only when the dose was considerably improved or supplemented with different sources of manure, whose long-term sustainability depends on the quantity and quality of the organic fertilizers applied, yield of crops, and quality and price of the product. Top-dressing fertilization in the dry season and with leguminous crops in the wet season maximized the yields of okra in a study conducted by Adekiya et al. (2017).

In studies carried out by Nascimento et al. (2013) on the quality of okra fruits, under saline stress, these authors observed similar values to those found here for SS (5.13 to $5.37^{\circ}$ Brix). Conversely, Carnelossi et al. (2005), working with minimal processing of okra, found higher contents
A.

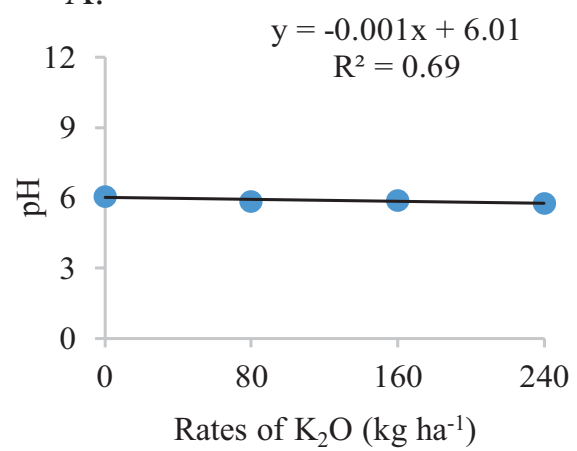

B.

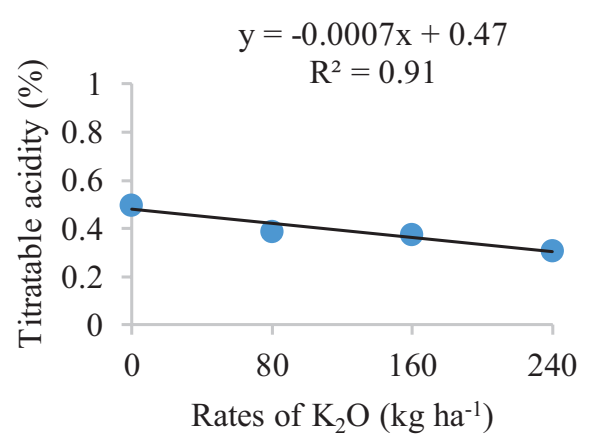

C.

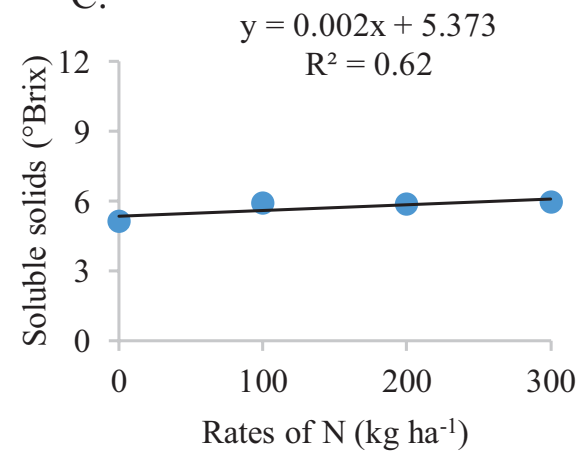

Figure 2. pH (A), titratable acidity (B) and soluble solids $(\mathrm{C})$ in okra fruits produced under different doses of $\mathrm{K}_{2} \mathrm{O}$ 
Table 4. Quality of okra fruits produced with organic fertilization

\begin{tabular}{cccccc}
\hline $\begin{array}{c}\text { Organic fertilization } \\
(\mathrm{t} \mathrm{ha-1})\end{array}$ & $\mathrm{pH}$ & $\begin{array}{c}\text { Electrical conductivity } \\
\left(\mathbf{m S ~ c m}^{-1}\right)\end{array}$ & $\begin{array}{c}\text { Soluble solids } \\
\left({ }^{\circ} \mathrm{Brix}\right)\end{array}$ & $\begin{array}{c}\text { Ascorbic acid } \\
\left(\mathbf{m g ~ 1 0 0 g}^{-1}\right)\end{array}$ & $\begin{array}{c}\text { Titratable acidity } \\
(\%)\end{array}$ \\
0 & $5.87 \mathrm{a}$ & $11.07 \mathrm{a}$ & $5.81 \mathrm{a}$ & $4.12 \mathrm{~b}$ & $0.37 \mathrm{~b}$ \\
30 & $6.06 \mathrm{a}$ & $9.19 \mathrm{a}$ & $5.93 \mathrm{a}$ & $6.28 \mathrm{a}$ & $0.50 \mathrm{a}$ \\
\hline
\end{tabular}

Means followed by the same letter, in the columns, do not differ by Tukey test at 0.05 probability level

than those observed in the present study for ascorbic acid

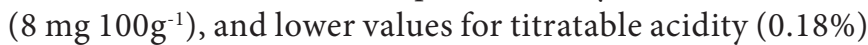
and $\mathrm{pH}$ (4.7). According to Petropoulos et al. (2018), the practice of harvesting okra fruits when they are still small helps increase their nutritional value.

There are few studies in the literature on the nutrition of okra plants and even fewer on its influence on post-harvest quality. This study will serve as basis for future research aiming at quality production of okra in the region, which has climate conditions that are favorable to the development of this crop.

\section{Conclusions}

1. Okra is demanding in terms of potassium and nitrogen fertilization.

2. The mean number and diameter of okra fruits increased by 9.10 and $36 \%$, respectively, with potassium and nitrogen fertilization.

3. Organic fertilization increased the content of ascorbic acid in okra fruits by $52 \%$.

\section{Literature Cited}

Abd El-Kader, A. A.; Saaban, S. M.; Abd El-Fattah, M. S. Effect of irrigation levels and organic compost on okra plants (Abelmoschus esculentus L.) grown in sandy calcareous soil. Agriculture and Biology Journal of North America, v.1, p.225-231, 2010. https:// doi.org/10.5251/abjna.2010.1.3.225.231

Adekiya, A. O.; Aboyeji, C. M.; Dunsin, O.; Adebiyi, O. V.; Oyinlola, O. T. Effect of urea fertilizer and maize cob ash on soil chemical properties, growth, yield, and mineral composition of okra, Abelmoschus esculentus (L.) Moench. Journal of Horticultural Research, v.26, p.67-76, 2018. https://doi.org/10.2478/johr-20180008

Adekiya, A. O.; Agbede, T. M.; Aboyeji, C. M.; Dunsin, O. Response of okra (Abelmoschus esculentus (L.) Moench) and soil properties to different mulch materials in different cropping seasons. Scientia Horticulturae, v.217, p.209-216, 2017. https://doi.org/10.1016/j. scienta.2017.01.053

Alegbejo, M.; Ogunlana, M.; Banwo, O. Survey for incidence of okra mosaic virus in northern Nigeria and evidence for its transmission by beetles. Spanish Journal of Agricultural Research, v.6, p.408411, 2008. https://doi.org/10.5424/sjar/2008063-342

AOAC - Association of Official Analytical Chemists. Official methods of analysis of the Association of Official Analytical Chemists. 18.ed. Gaithersburg: AOAC, 2005. 3172p.

Babatola, L. A. Effect of NPK 15:15:15 on performance and storage life of okra (Abelmoschus esculentus). Proceedings of the Horticultural Society of Nigeria Conference, v.2, p.125-128, 2006.

Brasil. Ministério da Agricultura, Pecuária e Abastecimento. Levantamento exploratório-reconhecimento de solos do estado da Paraíba. Rio de Janeiro: MAPA, 1972. 683p.
Cardoso, M. O.; Berni, R. F. Nitrogen applied in okra under non-tightness grown and residual fertilization. Horticultura Brasileira, v.30, p.645-652, 2012. https://doi.org/10.1590/S010205362012000400014

Carnelossi, M. A. G.; Yaguiu, P.; Reinoso, A. C. L.; Almeida, G. R. de O.; Lira, M. L.; Silva, F. G. da; Jalali, V. R. R. Determinação das etapas do processamento mínimo de quiabo. Horticultura Brasileira, v.23, p.970-975, 2005. https://doi.org/10.1590/S010205362005000400022

CFSMG - Comissão de Fertilidade do Solo do Estado de Minas Gerais. Recomendação para o uso de corretivos e fertilizantes em Minas Gerais: $5^{\text {a }}$ Aproximação. Viçosa: Comissão de Fertilidade do Solo do Estado de Minas Gerais, 1999. 359p.

Daliparthy, J.; Barker, A. V.; Mondal, S. S. Potassium fractions with other nutrients in crops: A review focusing on the tropics. Journal of Plant Nutrition, v.17, p.1859-1886, 1994. https://doi. org/10.1080/01904169409364852

EMBRAPA - Empresa Brasileira de Pesquisa Agropecuária. Sistema brasileiro de classificação de solos. 3.ed. Brasília: Embrapa Informação Tecnológica, 2013. 353p.

EMBRAPA - Empresa Brasileira de Pesquisa Agropecuária. Manual de métodos de análise de solos. 3.ed. Brasília: Embrapa Informação Tecnológica, 2017. 573p.

Filgueira, F. A. R. Novo manual de olericultura: Agrotecnologia moderna na produção e comercialização de hortaliças. 3.ed. Viçosa: UFV, 2008. 421p.

Kamaluldeen, J.; Yunusa, I. A. M.; Zerihun, A.; Bruhl, J. J.; Kristiansen, P. Uptake and distribution of ions reveal contrasting tolerance mechanisms for soil and water salinity in okra (Abelmoschus esculentus) and tomato (Solanum esculentum). Agricultural Water Management, v.146, p.95-104, 2014. https://doi.org/10.1016/j. agwat.2014.07.027

Malavolta, E.; Gomes, F. P.; Alcarde, J. C. Adubos e adubações. São Paulo: Nobel, 2002. 200p.

Marin, M. V.; Santos, L. S.; Gaion, L. A.; Rabelo, H. O.; Franco, C. A.; Diniz, G. M. M.; Silva, E. H. C.; Braz, L. T. Selection of resistant rootstocks to Meloidogyne enterolobii and $M$. incognita for okra (Abelmoschus esculentus L. Moench). Chilean Journal of Agricultural Research, v.77, p.58-67, 2017. https://doi. org/10.4067/S0718-58392017000100007

Nascimento, I. B.; Ferreira, L. E.; Medeiros, J. F. de; Aroucha, E. M. M.; Souza, C. M. G.; Cavalcanti, N. K.; Izídio, N. S. de C. Qualidade pós-colheita de quiabo submetido a diferentes lâminas de água salina. Agropecuária Científica no Semiárido, v.9, p.88-93, 2013.

Oliveira, A. P. de; Alves, A. U.; Dornelas, C. S. M.; Silva, J. A.; Porto, M. L. Rendimento de quiabo em função de doses de nitrogênio. Acta Scientiarum. Agronomy, v.25, p.265-268, 2003. https://doi. org/10.4025/actasciagron.v25i2.1761

Oliveira, A. P. de; Dornelas, C. S. M.; Alves, A. U.; Alves, A. U.; Silva, J. A. da; Oliveira, A. N. P. de. Resposta do quiabeiro às doses de fósforo aplicadas em solo arenoso. Horticultura Brasileira, v.25, p.180183, 2007. https://doi.org/10.1590/S0102-05362007000200010 
Oliveira, A. P. de; Silva, O. P. R. da; Silva, J. A.; Silva, D. F. da; Ferreira, D. T. A. de; Pinheiro, S. M. G. Produtividade do quiabeiro adubado com esterco bovino e NPK. Revista Brasileira de Engenharia Agrícola e Ambiental, v.18, p.989-993, 2014. https:// doi.org/10.1590/1807-1929/agriambi.v18n10p989-993

Omatoso, S. O.; Shittu, O. S. Effect of NPK fertilizer rates and method of application on growth and yield of Okra (Abelmoschus esculentus (L.) Moench) at Ado-Ekiti Southwestern, Nigeria. International Journal of Agricultural Research, v.2, p.614-619, 2007. https://doi.org/10.3923/ijar.2007.614.619

Petropoulos, S.; Fernandes, A.; Barros, L.; Ferreira, I. C. F. R. Chemical composition, nutritional value and antioxidant properties of Mediterranean okra genotypes in relation to harvest stage. Food Chemistry, v.242, p.466-474, 2018. https://doi.org/10.1016/j. foodchem.2017.09.082

Phonglosa, A.; Bhattacharyya, K.; Ray, K.; Mandal, J.; Pari, A.; Banerjee, H.; Chattopadhyay, A. Integrated nutrient management for okra in an inceptisol of eastern India and yield modeling through artificial neural network. Scientia Horticulturae, v.187, p.1-9, 2015. https://doi.org/10.1016/j.scienta.2015.02.037

Pinheiro, S. M. G.; Silva, D. F.; Oliveira, A. N. O.; Barros, J. R. A.; Silva, O. P. R. Rendimento do quiabo em função de doses de esterco bovino e NPK. In: Congresso Brasileiro de Olericultura, 51, 2011, Viçosa. Anais... Viçosa: ABH, 2011. p.3717-3724.

Pitan, O. O. R.; Ekoja, E. E. Yield response of okra, Abelmoschus esculentus (L.) Moench to leaf damage by the flea beetle, Podagrica uniforma Jacoby (Coleoptera: Chrysomelidae). Crop Protection, v.30, p.1346-1350, 2011. https://doi.org/10.1016/j. cropro.2011.06.004
Pradeepkumar, T.; Bonny, B. P.; Midhila, R.; John, J.; Divya, M. R.; Roch, C. V. Effect of organic and inorganic nutrient sources on the yield of selected tropical vegetables. Scientia Horticulturae, v.224, p.84-92, 2017. https://doi.org/10.1016/j.scienta.2017.04.022

Raij, B. van; Cantarella, H.; Quaggio, J. A.; Furlani, A. M. C. Recomendações de adubação e calagem para o estado de São Paulo. 2.ed. Campinas: Instituto Agronômico de Campinas, 1996. 285p. Boletim Técnico, 100

Ryan, J. J.; Dupont, J. A. Identification and analysis of the major acids from fruit juices and wines. Journal Agricultural and Food Chemistry, v.21, p.45-49, 1973. https://doi.org/10.1021/jf60185a018

Silva, M. B.; Costa, C. R.; Costa, A. S. V.; Prezzoti, L. 101 Culturas: Manual de tecnologias agrícolas. Belo Horizonte: EPAMIG, 2007. 653p.

Thornthwaite, C. W. An approach towards a rational classification of climate. Geographical Review, v.38, p.55-94, 1948. https://doi. org/10.2307/210739

Tiamiyu, R. A.; Ahmed, H. G.; Muhammad, A. S. Effect of sources of organic manure on growth and yields of okra (Abelmoschus esculentus L.) in Sokoto, Nigeria. Nigerian Journal of Basic and Applied Science, v.20, p.213-216, 2012.

Tivelli, S. W.; Kano, C.; Purqueira, L. F. V.; Wutke, E. B.; Ishimura, I. Desempenho de quiabeiro consorciado com adubos verdes eretos de baixo porte em dois sistemas de cultivo. Horticultura Brasileira, v.31, p.483-488, 2013. https://doi.org/10.1590/S010205362013000300023

Turrent, F. A. Uso de una matriz mixta para la optimizacion de cinco a ocho factores controlables de la produccion. Chapingo: Colegio de Postgraduados, 1979. 65p. Boletim Técnico, 6 